\title{
FOSTERING MILLENNIAL ENTREPRENEURSHIP STUDENTS - ISSUES AND CHALLENGES
}

\author{
Noor Azuan Hashim*), Farhana Sidek*), Shifa Mohd Nor*) \\ ${ }^{*}$ Faculty of Economics and Management, Universiti Kebangsaan Malaysia \\ 43600 UKM Bangi, Selangor, Malaysia
}

\begin{abstract}
Governments worldwide have increasingly recognized their interest in entrepreneurship and have introduced it to various settings, not only among the officials but also schools and Higher Education Institutions (HEI). Many incentives have been given to those who embark on entrepreneurship. The Malaysian government has made all colleges in Malaysia introduce entrepreneurships courses to make students aware of the importance of entrepreneurships. Thus, there are questions were raised on the effectiveness of the entrepreneurship programme in the university. Moreover, and the kinds of improvements that need to be embedded in these programmes. This study is among the first to explore this issue by gathering information from the students majoring in entrepreneurship and who are recently graduated. Both quantitative and qualitative methods have been adopted to get the details of the issues being studied. Thirty-three students were surveyed, and ten respondents were called for semi-structured interviews. Many students stated that they were not ready to become an entrepreneur entrepreneurs because they are were really not confidence confident in doing so, and some said they needed to work to get some money and experience first. Some stated that the programme should be improved by creating an entrepreneurship ecosystem among students and lecturers. This study contributes to entrepreneurship education literature by enhancing understanding of the needs of students during the entrepreneurial learning process. In practice, this study offers raze and valuable insights into how to design and implement designing and implementing an effective HEI entrepreneurship training programme.
\end{abstract}

Keywords: entrepreneurship, entrepreneurship education, effectiveness, higher learning institution, Malaysia

\begin{abstract}
Abstrak: Pemerintah di seluruh dunia semakin menyadari minat mereka terhadap kewirausahaan dan telah memperkenalkannya ke berbagai lingkungan, tidak hanya di kalangan pejabat tetapi juga sekolah dan Higher Education Institutions (HEI). Banyakinsentif telah diberikan kepada mereka yang memulai kewirausahaan. Pemerintah Malaysia telah membuat semua perguruan tinggi di Malaysia memperkenalkan mata kuliah kewirausahaan untuk menyadarkan mahasiswa akan pentingnya berwirausaha. Dengan demikian, muncul pertanyaan tentang efektivitas program kewirausahaan di universitas. Selain itu, dan jenis perbaikan yang perlu ditanamkan dalam program-program ini. Studi ini termasuk yang pertama untuk mengeksplorasi masalah ini dengan mengumpulkan informasi dari mahasiswa jurusan kewirausahaan dan yang baru saja lulus. Kedua metode kuantitatif dan kualitatif telah diadopsi untuk mendapatkan rincian masalah yang sedang dipelajari. Tiga puluh tiga siswa disurvei, dan sepuluh responden dipanggil untuk wawancara semi-terstruktur. Banyak mahasiswa yang menyatakan belum siap menjadi wirausahawan karena sebenarnya tidak percaya diri untuk melakukannya, dan ada juga yang mengatakan perlu bekerja untuk mendapatkan uang dan pengalaman terlebih dahulu. Beberapa pihak menyatakan bahwa program tersebut harus ditingkatkan dengan menciptakan ekosistem kewirausahaan di kalangan mahasiswa dan dosen. Studi ini berkontribusi pada literatur pendidikan kewirausahaan dengan meningkatkan pemahaman tentang kebutuhan siswa selama proses pembelajaran kewirausahaan. Dalam praktiknya, studi ini menawarkan wawasan yang luas dan berharga tentang bagaimana merancang dan mengimplementasikan merancang dan mengimplementasikan program pelatihan kewirausahaan HEI yang efektif.
\end{abstract}

Kata kunci: kewirausahaan, pendidikan kewirausahaan, efektivitas, institusi pendidikan tinggi, Malaysia

${ }^{1}$ Corresponding author:

Email: azuan@ukm.edu.my 


\section{INTRODUCTION}

A topic that attracts the most attention among academicians and journalists is Entrepreneurship. Researchers have been focusing on the function of an entrepreneur, which is to serve the economy (Sugiato et al. 2014; Shane et al. 2003). The concept of entrepreneurship can be understood as a process of vision, change and creation. The act of entrepreneurship needs a certain amount of energy and passion for creating and implementing new ideas. There seems to be an agreement that the act of entrepreneurship involves creating something new (Jolanda, 2008). In addition, entrepreneurship can be interpreted as a "process" rather than a one-time event, action or decision. It is all based on the level of creativity a person has to uncover new ideas and arrange the resources in ways that have not been done before (Sugiato et al. 2014).

Entrepreneurship is an essential concept for discovering opportunities and stimulating growth. It has become a powerful tool for creating jobs and improving economic power in the labor market and economy as a whole (Byun et al. 2018). It is more evident with the advent of the fourth industrial revolution (4IR) that various competencies such as creativity, innovation, and agility are required for start-ups (Kim et al. 2017). In addition, Omoruyi et al. (2017) found a positive relationship between entrepreneurship and economic development. They suggested that to decrease the unemployment rate and stimulate economic growth in a country, and the entrepreneurial spirit should be fostered from an early age. Entrepreneurship education and entrepreneurship courses have been introduced to nurture students to be future entrepreneurs. Most institutions currently provide entrepreneurial training programs believing that the importance of entrepreneurship and the knowledge and skills needed to become an entrepreneur can be taught. Thus, the proportion of policy support toward entrepreneurship education has been increasing in many countries worldwide (O'Connor, 2013; Walter and Block, 2016).

Following the same vein in other countries, the Malaysian government has taken an active role in establishing entrepreneurship education (Rahim et al. 2015). Many initiatives have encouraged nations, particularly students, to venture out or set up their businesses. All Higher Education Institutions (HEI) in Malaysia are now offering entrepreneurship courses in line with the government's aspiration to have more successful entrepreneurs and a true entrepreneurial nation by 2030 as stated in Malaysian National Entrepreneurship Policy 2030 (NEP 2030), launched on $11^{\text {th }}$ July 2019. Despite the initiatives given, not many students, particularly those majoring in entrepreneurship, have embarked on being entrepreneurs.

There are many discussions on entrepreneurs and entrepreneurship. Scholars have put forward several theories to explain these concepts. These theories have their roots in many topics such as economics, psychology, sociology, anthropology, and management. Among the earliest discussion on entrepreneurs was put forward by Cantillon in the early 1700s, who described an entrepreneur as someone who bears risk by buying at specific prices and selling at uncertain prices (Carton et al. 1998). Following Cantillon, Jean Baptiste Say broadened the definition to include the concept of combining factors of production, also noting that the entrepreneur must have particular personal qualities (Stevenson and Jarillo, 1990). The entrepreneur is the individual or team that identifies the opportunity, gathers the necessary resources, creates and is ultimately responsible for the consequences of the organization (Carton et al. 1998). Among the prominent concept of entrepreneurship introduced by Schumpeter (1934), he defined entrepreneurs as "The carrying out of new combinations we call "enterprise"; the individuals whose function it is to carry them out we call "entrepreneurs."....everyone is an entrepreneur only when he actually "carries out new combinations," and loses that character as soon as he has built up his business when he settles down to running it as other people run their businesses (p.74).

Regardless of how researchers debate, discuss and critics about entrepreneurs and entrepreneurship, it is commonly accepted that an entrepreneur is a person who sets up a business with the aim to make a profit, while entrepreneurship is about getting out into the world, doing it and makes it happen (Di Meglio, 2013). Entrepreneurship is simply researching, writing or reading (Di Meglio, 2013). It is the process of designing, launching and running a new business, which is often initially a small business. The people who create these businesses are called entrepreneurs. In order to be an aspiring entrepreneur, one needs to acquire knowledge, both explicit and tacit knowledge (Byun et al. 2018). With this knowledge, entrepreneurs can spot opportunities, act on them, and profit from them (Fernandes, 2019). 
An entrepreneur can be a person who first sells its products/services, sets up the first online store on the side, or is a freelancer just starting. He/she can also be someone who starts a side hustle that eventually can create a full-time, sustainable business with employees. In addition, an entrepreneur also is someone who organizes, manages, and assumes the risks of a business or enterprise (Merriam-Webster, 2019). The good thing is that entrepreneurs see possibilities and solutions, find an idea and turn it into a business (Drucker, 2007), while an average person does not. Entrepreneurs are the doer rather than the observer. They capture an idea and execute it. They are the leaders that strike out on their own to improve society (Drucker, 2014; Fernandes, 2019). Thus, understanding what an entrepreneur is can help more people recognize the value, they contribute to the world.

Entrepreneurs have much to give to society. Their contribution to the welfare of society is of high order (Rahim et al. 2015). In a market full of uncertainty, the entrepreneur can help clarify uncertainty as he makes judgments or assumes the risk (Fernandes, 2019). Recognizing the importance of entrepreneurship for the economy, governments in both developed and developing nations have moved many of their policies from being directed towards a managed economy to an entrepreneurial economy (Omoruyi et al. 2017). In addition, the inability of some graduates of the educational system to get proper jobs of their qualification has encouraged the government everywhere to introduce entrepreneurship education in colleges and universities (Byun et al. 2018). Part of the reason is to spark all these graduates not only as job seekers but also to have the courage to become job creators. Through this effort, it is believed that this effort can lead to less unemployed graduates and an increase in business opportunities, which will have a direct impact on the economy, particularly on achieving the developed nation status (Omoruyi et al. 2017) as envisioned by many developing countries such as Malaysia.

Paolucci et al. (2019) advocated that entrepreneurship education seeks to provide students with the knowledge, skills and motivation to encourage entrepreneurial success in various settings. It prepares people to be responsible and enterprising individuals. In addition, it also helps people develop the attitudes necessary to achieve the goals they set out for themselves (Omoruyi et al. 2017). Furthermore, entrepreneurship education also focuses on developing skills or attributes that enable the realization of opportunity, which are divergent from management education that focuses on the best way to operate existing hierarchies (Paolucci et al. 2019). Entrepreneurship education is essential for economic development and improving the quality and quantity of future entrepreneurs (Syed et al. 2011). Evidence shows that people with entrepreneurial education are more employable than those not (European Commission, 2019).

In Malaysia, the Malaysia Ministry of Higher Education has made entrepreneurship subjects compulsory for all students in the public HEI. Higher Education Entrepreneurship Development Policy was launched on 13th April 2010 by the Ministry of Education (MOE) to boost the development of more holistic and wellorganized entrepreneurship programs. Specifically, the implementation of the policy aims to produce graduates from Higher Education Institutions (HEIs) with thinking and entrepreneurial attributes as well as to increase the number of entrepreneurs among graduates who are engaged in businesses as a catalyst for the achievement of economic transformation in the country (Rahim et al. 2015). It also aims to increase the number of people from a middle to a high-income economy and at the same time to produce more academics with values, skills, thoughts, and entrepreneurship qualities. In addition to the policy, the Entrepreneurship Action Plan of Higher Education Institutions (2016-2020) (MOHE, 2019) was rolled out by the Ministry of Higher Education (MOHE) in 2016 to promote entrepreneurship education and entrepreneurship development in institutions. Moreover, to instill entrepreneurial mindsets and behaviors into all students and those seeking to become graduate entrepreneurs (Sani, 2018). The four initiatives include high-impact education practices, a job creator framework, improving the student entrepreneur development support ecosystem and strengthening the entrepreneur teaching force competency. Recently, the Malaysian government has launched the National Entrepreneurship Policy 2030 (NEP 2030). It aims to empower the B40 (the bottom $40 \%$ of households with monthly income below USD1000), inculcating a culture of entrepreneurship. It has even strengthened the need of having entrepreneurship education in the early years. 
According to Rahim et al. (2015), Malaysia's entrepreneurship education is moving forward in the right direction. Students were encouraged to participate in class and take part in many entrepreneurship activities at their respective universities - training programs, seminars, short courses, conferences, and entrepreneurship events. A study by Badariah et al. (2016) advocated that entrepreneurship education programs offered by the Malaysian public university were very effective in enhancing students' entrepreneurial skills. Thus, it is expected that more graduates become entrepreneurs now and that they are doing well. However, despite this promising anecdote, not many graduates are becoming entrepreneurs. Some issues and challenges persist, and researchers still try to understand the real issues.

This program was launched in the Faculty of Economics and Management (FEP) in the 2013/2014 session. It involved 27 students as the first cohort to join this program. The objectives of the program are to i) educate and produce graduates who can create their job opportunities, ii) instill entrepreneurial qualities and innovative characteristics among graduates, iii) inculcate leadership and managerial skills among graduates, and also iv) produce graduates who are experts in negotiation and promote business ideas to the market (FEP, 2019). The duration of the study is six semesters (three years) for full-time students. Students are needed to complete all 122 credit hours to fulfill the graduation requirements. They need to complete the university and faculty compulsory courses within these three years and at the same time need to complete 22 entrepreneurship and innovation courses (approximately 70 hours) that were designed for them by a few experts previously. Before they can take these 22 courses, students must enroll in LMCW1022 Introduction to entrepreneurship course.

Three cohorts of students have completed the study. One more cohort (Cohort 4) will be attending their graduation this November, while currently, cohort 5 and 6 are still pursuing their degree. Analysis from students who have graduated (Cohort 1, 2 and 3) shows most of them are working, and few continue to do their master's degree. However, only a small number of students embark as entrepreneurs. The majority of them work in any agency regardless of their area of study. The recent cohort who just completed their degree are still waiting to set up a business, work, or continue their study. It is expected that some of them have started their business since they have completed all the entrepreneur courses. However, it is still unknown to what extent they have embarked on being entrepreneurs or working for others.

In order to understand the issue in detail, a few entrepreneurship theories have been considered. This study is exploratory, and no causal effect is being investigated. It looks at students' opinions on their courses in the entrepreneurship programme; thus, theory based on social cognitive and experience is explored. It employs the theory of social cognition to examine how learners in entrepreneurship education can enhance their ability to identify opportunities, affecting entrepreneurs' innovative awareness, innovative ability, and innovative personality (Wei et al. 2019). According to Bandura (2018), social cognitive theory conceives individuals as agents and active contributors to developing the circumstances that surround their lives. Individuals are tended to pursue their goals if they consider their abilities and actions are capable of achieving the desired results (Bandura et al. 2003). Through entrepreneurship education, students can improve their cognition, constantly adjust their thoughts and actions, and make their entrepreneurship more directional, coherent and meaningful. Based on the theory, two propositions were placed: 1) Students can be entrepreneurs after they completed their learning of the courses offered in the programs, and 2) Students need more encouragement to make their learning meaningful.

There are rarely studies on this issue and a lack of studies that directly tackle opinions from respondents. Thus, this study intends to understand their current situation, issues and challenges about this program and the courses. It aims to explore the reason behind these entrepreneurship students rarely becoming entrepreneurs. Specifically, what are the issues and challenges that these graduates faced, do they want to be entrepreneurs, are the courses designed for them well enough, and what sorts of motivations do these potential entrepreneurs need to become real entrepreneurs, as well as what are the factors that motivate and inhibit them of doing so. It is hoped that this research can explain the issues being studied so that more improvement can be made and more issues can be solved, particularly in the entrepreneurship program. 


\section{METHODS}

The research was designed as a mixed-method consisting of quantitative and qualitative studies. The quantitative approach purports to focus more on discovering underlying meanings and patterns of relationships, including classifications of phenomena and entities (Goertzen, 2017). It is the systematic empirical investigation of observable phenomena via statistical, mathematical, or computational techniques (Lisa, 2008). In addition, semi-structured interviews were also being carried out to understand the issues or challenges faced by the respondents. This method allows researchers to question interviewees closely on the significant constraints and incentives encountered.

All thirty-three students in Bachelor in Entrepreneurship and Innovation (BEI) are waiting for their graduations were the primary respondents of this research. They were chosen because they have just completed their undergraduate studies, and at the same time, their minds are still fresh with the topics and courses they have taken. A questionnaire with 34 items was designed in Google form was sent to them via email. The item in the questionnaire was adapted from the course evaluation survey available online, including students' demographics, the courses they have taken, their activities in college, and the kinds of businesses they embarked on. According to Sekaran and Bougie (2016), questionnaire through the Internet is the most convenient way to get feedback as they are much simpler and cheaper to reach respondents. Through a link provided by this software, respondents can reach and answer the online survey provided they have access to the internet from various platforms such as email, websites, and even Facebook (Nagalakshmi and Treved, 2015). Respondents' data updates can be seen live, and the application processes result automatically (Harrsion, 2016). Many researchers have started using this Google form to gather data from broad geographical surveys (Nagalakhmi and Trevedi, 2015; Harrison, 2016). Data were then analyzed using SPSS software. All thirty-three students completed the questionnaire.

In addition to the questionnaire, semi-structured interviews were used to understand the issues being studied. Ten available respondents were called to attend short interview sessions. The questions include how they think about the courses being offered in the programme, what they will do if they were given a chance to start the programme over again, and improvements to strengthen the course. All these interviews were tape-recorded using an intelligent phone recorder and transcribed. Quotes that were relevant to the issues being studied were selected.

\section{RESULTS}

Four parts were developed in the questionnaire for data collection. All the data were analyzed using Excel and Statistical Packages for the Social Science (SPSS) software.

\section{Respondent Profile}

As mentioned earlier, 33 respondents have posted their answers on the google form link. Most of the respondents used smartphones, and most of them were using iPhone, Samsung or Huawei to answer the survey. Some of the respondents have more than one phone, and some have a dedicated phone for social networking activities, particularly on Instagram. As expected, most of them are very young since they are all undergraduate students, aged between 21 to 27 years old, and the majority are Malays. Their source of income while studying is mainly from loans such as The National Higher Education Fund (PTPTN) and government loans. Not many are self-funded or parents' sponsored. Table 1 displays the respondent characteristics.

Table 1 depicts the respondents' characteristics. The majority of the respondents are 22 years old, which is expected as they left school at 18. They joined Matriculation for a year and registered as university students, and graduated after three years. Interestingly, at least two important distributions in this respondent profile are gender and household income. Like most other universities in Malaysia, more female than male students are. Female now has taken the role in not only universities but also elsewhere. There are more females now working in both public and private sectors and being entrepreneurs. As expected, most of the respondents come from the B40 income group of which their parents' monthly household income is less than USD1000. This income group is considered under poverty and gets the most support from government policies such as the Life Support Programme, e-Kasih, and fuel subsidies. In order to get this support, people need to show proof of their salary and register with the government. Usually, they were given an ID card and with this card that could get the subsidy that the Malaysian government granted. 
Table 1. Respondents' characteristics $(\mathrm{N}=33)$

\begin{tabular}{lc}
\hline Characteristics & $\%$ \\
\hline Age & \\
21 & $9.10 \%$ \\
22 & $60.60 \%$ \\
23 & $18.10 \%$ \\
24 & $6.2 \%$ \\
25 & $3 \%$ \\
27 & $3 \%$ \\
Gender & \\
Male & $27.30 \%$ \\
Female & $72.70 \%$ \\
Ethnicity & \\
Chinese & $12.20 \%$ \\
Malay & $84.80 \%$ \\
Indian and others & $3 \%$ \\
Source of income & \\
Loan & $78.80 \%$ \\
Parents' sponsored & $18.20 \%$ \\
Others & $3 \%$ \\
Parents' monthly household income & \\
Less USD250 & $8 \%$ \\
USD250-USD500 & $13 \%$ \\
USD501-USD750 & $25 \%$ \\
USD751-USD1000 & $32 \%$ \\
More than USD1000 & $22 \%$ \\
\hline &
\end{tabular}

\section{Student Involvement in Business}

The majority of the respondents did not have a business yet, which is acceptable because there are still students attending their convocation soon. One interesting fact is that although they are still students, more than $30 \%$ of these respondents have their own business, whether they start a small business of their own or they become an agent of stockist or drop shippers for other products. Although this program does not require students to own a business, some of these respondents have taken the initiative. Interestingly, some of them have made sales up to USD750 a month.

"I sell all kind of things on Lazada and Shoppe. I become an agent for several products to earn some income. I am glad I manage to do, at least I do not need to ask for my parents for allowance."

Respondent 1

"I own a business with my friends in Bangi. We give services on design and all sort of things on media. So far so good. I need to expand my business after I finish this programme." Respondent 2
Sixteen respondents in the survey claim that their parents own a business. However, eleven of these respondents do not seem interested in continuing with their family business. Most of them want to experience working in a company or find their path. Only five of them consider joining their parents' business. Interestingly, $15 \%$ of the respondents whose parents did not own any business or have never experienced business before own a business.

"When I first join this programme, I have already known what I want. I just need time to gather things. That is why I try to arrange my class as minimum days as I can so that I can also concentrate on my business. But Doc, it is just a small business."

Respondent 3

"My parents did not pressure me on my career path. They allow me what I want do or venture out. They are my great supporters. I will make sure my business will fly high. But I don't know when this happen. Just need to try."

Respondent 2

\section{Student Involvement in Activities}

More than half of the respondents in the survey $(57.6 \%)$ said that they benefited from the program. They found that the program has groomed them from novice to someone who has more knowledge about what entrepreneurship is all about. The majority of the respondents stated that if they were given another chance to start their first year again, they wanted to perform better, start their own business, and join all sorts of activities designed for the student regardless of whether it is inter-faculties program or inter-universities. Many have regretted doing so. Almost three-quarters of the respondents stated:

"We wish that we have started our business earlier. With the help of the lecturers and faculty we can grow faster and better." Respondent 10

"We wish that we can think like this previously. There is so many opportunities in the university. But we don't really care because we thought life in university is just to study and pass the exam."

Respondent 8

"Our mistakes. Every weekend we think of going back to our hometown. We forgot to take up the opportunities here. It is hard but some of friends have made through. We are proud of them."

Respondent 2

"Hah! Can we just turn the clock back?" Respondent 6 
Interviewed respondents claim that most entrepreneurship students are less receptive to the program during their first year. They stated that the first year of the entrepreneurship introduction course (LMCW1022) is hectic because there are too many tasks. They need to make presentations, play business simulation games, attend seminars and talks, pitch their business, compete with other faculties, and sell. According to some of the interviewers, some students have become discouraged with these kinds of tasks because they have a handful of tasks to accomplish. On the other hand, some students who can be considered entrepreneurial mindsets found the opportunity in this course, but the number is too few. These students usually went to the Centre for Entrepreneurship \& SME's Development (UKM-CESMED - center responsible for providing services and advice to academic and Non-academic entrepreneurs for UKM) to seek further help to attend more entrepreneurs advance courses. At the same time, those majoring in entrepreneurship in FEP still need to continue with the program because they are compulsory to take the course to graduate. Altogether, there are 22 entrepreneurship courses these BEI students need to take after introducing an entrepreneurship course. Although there are some issues and criticism about some of these 22 courses, interestingly, the majority of the respondents asserted that all courses designed for them are suitable to prepare them to be entrepreneurs.

"I wish to have more hands-on courses like these. It helps us to think more creatively and innovatively." Respondent 7 "There are so many projects we need to handle; some
are relevant but not others."

Respondent 2

\section{Lecturers' Involvement in Activities with Students}

The majority of respondents agree that lecturers play an essential part in their journey to pursue a degree in entrepreneurship and keep them motivated, consistent with most HEI findings (Kamaruddin et al, 2017; Aziz and Kazi 2019). Almost half of the respondents stated that some lecturers delivered their course conventionally. Lectures in the classroom are given weekly and focus more on quizzes, assignments and exams. This approach is not suitable for these respondents since they need many hands-on activities. The majority of the respondents need activity outside the classroom such as industrial visits, training, talks from succeed and experienced entrepreneurs, and more networking. They stated that entrepreneurs do not seat in class but move around with objectives. They required more experience and motivated lecturers to handle these entrepreneurship courses. For them, "chalk and talk" does not work $100 \%$ in today's education but more on meaningful learning experience entrepreneurial visits.

"These modules developed interpersonal skill such as creating a creative thinking skill and being proactive.

The learning process and environment are efficient and the lecturers are competent and dedicated upon teaching the courses."

Respondent 9

"For student entrepreneurs like us, we really need hands-on matters. Teaching traditionally mostly in classroom is not really relevant for us anymore."

Respondent 1

"Please, please,please! We need to meet more entrepreneurs in all sorts of industries. Can we get them in this programme? We also need encouragement how to register our company.'

Respondent 4

Despite the criticism, most of the courses offered are rated as either very good or excellent (more than $75 \%$ of respondents rated the courses as in these two categories). Not even $25 \%$ of the respondents claim that the course is unsatisfactorily for each course. It means that all courses offered in this BEI program are considered very good or excellent. Interestingly, none of the courses offered in this program is rated as poor. Only a few respondents suggested that new courses such as industrial training, project paper, social business, and big data analysis should be introduced.

"I think courses like big data analysis and digital marketing should be introduced in this program. We are talking about doing business online nowadays. Thus, we demand this course in this program."

Respondent 8

\section{Students' Opinion on the Programs}

Respondents were asked to state their opinions on anything they like or dislike about the program. Openended questions were given to them in the questionnaire. They were asked to state three things they like about the programme and three things they do not. More than 60 opinions on likes and dislikes were listed down from all respondents. These responses were rearranged according to the theme. Those who stated their opinions in the Malay language were translated to English. There are five themes discovered in their responses: 


\section{Motivation}

The majority of the respondents stated they needed the motivation to embark on their own business. They concluded that some lecturers motivate them quite well because they feel they can venture into so many businesses. Paolucci and Fiore (2019) also claimed that students need skills and motivation to promote entrepreneurial success. At the same time, other respondents stated that some lecturers are good at giving lectures but not in encouraging students to carry out activities or even to start their business. In fact, according to them, some lecturers themselves were not motivated enough to teach some of these entrepreneurial courses. Part of the reason is that the lecturer has never owned or advised any business at all: "Many theories. Students sit in the classroom and listen to the lecturer. Not interactive enough for two ways communication."

\section{Industrial Engagement}

More than half of students stated that they are unclear about what they want to be after finishing their studies. The majority of them still wanted to look for a job. However, they felt that their degree in entrepreneurship and innovation is not suitable for working in a company. They were still skeptical about what they could offer to the company. They felt that other students majoring in other programs are luckier since they have experienced industrial training. Some dislikes' comments include: "No industrial offer in this program. Should include industrial training. I want to have working experience".

\section{Classroom Setting}

One of the comments that most respondents claims is about the classroom arrangement. They stated that classrooms such as lecture halls are not suitable for entrepreneurial students. They claimed that as entrepreneurs, they need a laboratory and incubatorstyle classroom to generate their ideas more creatively and efficiently. They wished that they could stay in a lab to do their projects and to put their ideas without having to move from one classroom to another: "Once the class finish, we need to go out. We need to book the classroom now and then to work on our project. Ideas sometimes come at night. No special room for us."

\section{Practical Tasks}

Another substantial comment is about the practical tasks that students need to do. The majority of respondents agreed that they needed to be hands-on and brush on their skills as an entrepreneur students. They needed active learning and more outside classroom activities such as industrial visits, attending seminars, training and others. Currently, not all of the courses offer active learning. Some courses still implement exams, and even some lecturers are too rigid with their slide lectures: "Some courses have no elaboration. Lecturers still read form slides. We want more practical stuff such as handling outside projects or public speaking for us to be more confident."

\section{Mentorship}

Respondents also asserted that they did not have a dedicated supervisor to guide them to be an entrepreneur during their course. They needed a mentor to guide them, which is similar to findings by Babatunde and El-Gohary (2019). Currently, the faculty only assigns one academic member to at least ten faculty students regardless of their background. Most of the assistance these respondents gave was about planning their studies or something to do with their academics. None of these academicians supervise them about the business they want to do. Most respondents either work on their tasks or seek help from the entrepreneur club advisors or the assistant dean. These are some support they got from the faculty. They wish to have a dedicated mentor for them to make sure their business proposal executes and the business becomes a reality: "I have no mentor to discuss my business. No dedicated staff to help me to run my business. We should have a successful business person to be our mentor."

\section{Managerial Implications}

Interestingly, some other findings emerge from this study. Motivation, industrial engagement, classroom setting, practical tasks, and mentorship are essential elements for students to develop their cognitive and learning skills (Bandura, 2018; Wei and Sha, 2019). Other studies also found that mentorship and motivation need to be embedded in the programme to encourage students to embark on any business projects (Babatunde and El-Gohary, 2019; Paolucci and Fiore, 2019). These findings can be added to the entrepreneurship education theory. These findings can also help the course designers 
or the academicians steer their programme towards what the students need. Students also asserted that they need information in setting up their business as early as the first year of study. In addition to the finding, one implication can be acknowledged that students need support in entrepreneurial skills. Academicians who teach these courses should also be experts on the theoretical and practical subject matter. To do that, they need to attend entrepreneurship courses, become members of some entrepreneurship societies, and even possibly own a business or work with the student to successfully execute the business. In addition, business talks and seminars with real entrepreneurs (whether a success or failure) and visits to entrepreneurs' sites should be more frequent. More information and knowledge can be learned, and more experiences can prepare students to be natural entrepreneurs.

Learning about entrepreneurship projects is an essential part in terms of entrepreneurship education. Entrepreneurship projects such as talks, seminars or visits are made to enhance university students in entrepreneurial skills. Therefore, University students should be supported by a positive learning environment to create an independent character, initiative action, goal-oriented, and collaborative personality.

\section{CONCLUSIONS AND RECOMMENDATIONS}

\section{Conclusions}

The results of this study have given some sorts of overviews about this entrepreneurship education program running in the university. It indicates some issues should be addressed to keep the students who choose entrepreneurship and innovation as their major. In general, most students are happy with the courses offered except three to four courses that they think need to be improvised. More digital and practical courses should be offered to be more hands-on to polish their skill. In addition, they also need some public speaking and negotiating skills to appear to be more confident.

\section{Recommendations}

This study focuses only on BEI students in the Faculty of Economics and Management. This program was just offered six years ago, and only three cohorts have graduated. Thus, this program is still new, and more improvements should be made to strengthen the program. The current study only focuses on students who are recently graduated. This study has gathered information, giving the program a new, possibly fresher, more inclusive perspective. Building on this present issue, there are opportunities for further work, especially on the key issue of profiling students who choose to embark on this program and how to help these students to achieve the country's intention to have more future entrepreneurs.

This study adopts only a small survey and interviews with students majoring in entrepreneurship and innovation, and it is a cross-sectional survey. Further investigation is needed to investigate other entrepreneurship programs in other universities, and more entrepreneurship students should be involved. It is interesting to explore the characteristics of these students in general. Future research should also embark on more rigorous methodology such as longitudinal studies using multivariate statistical analysis to provide a more robust conclusion on the issues being investigated.

\section{REFERENCES}

Aziz F, Kazi AS. 2019. Role of teachers in students' classroom participation in universities. International Journal of Educational Enquiry and Reflection 4(1):1-14.

Babatunde SA, El-Gohary H. 2019. Necessity of mentoring in entrepreneurship education: reflection by practitioners. Journal of Professional Issues in Engineering Education and Practice 143(1). https://doi.org/10.1061/(ASCE)EI.19435541.0000399

Badariah HD, Abdul Rahim A, Mariana U. 2016. The Entrepreneurship Education Program in Malaysian Public University. In ISSC 2016: International Soft Science Conference. hlm 443-449.

Bandura A. 2018. Toward a psychology of human agency: Pathways and reflections. Perspectives on Psychological Science 13:130-136. https:// doi.org/10.1177/1745691617699280

Bandura A, Caprara GV, Barbaranelli C, Gerbino M, Pastorelli C. 2003. Role of affective selfregulatory efficacy in diverse spheres of psychosocial functioning. Child Development 74:769-782. https://doi.org/10.1111/14678624.00567 
Byun CG, Sung CS, Joo Y, Park JY, Choi DS. 2018. A Study on the effectiveness of entrepreneurship education programs in higher education institutions: A case study of Korean Graduate Programs. Journal of Open Innovation: Technology, Market, and Complexity 426:1-14. https://doi.org/10.3390/joitmc4030026

Carton RB, Hofer CW 1998. Meeks MD: The Entrepreneur and Entrepreneurship: Operational Definitions of Their Role in Society. In Paper presented at the Annual International Council for Small Business Conference. Singapore.

Drucker P. 2007. Innovation and Entrepreneurship. UK: Butterworth-Heinemann Elsevier.

European Commission. 2019. Promoting entrepreneurship. https://ec.europa.eu/growth/ smes/promoting-entrepreneurship /support/ education_en. [14th July 2019]

FEP. 2019. Faculty economics and management website.http://www.ukm.my/fep/program/bachelorof-entrepreneurship-and-innovation. [14th July 2019]

Fernandes P. 2019. Entrepreneurship defined: What it means to be an entrepreneur. https://www. businessnewsdaily.com/7275-entrepreneurshipdefined.html. [10th August 2019].

Goertzen MJ. 2017. Introduction to quantitative research and data. Library Technology Reports 53(4):12-18.

Harrison C. 2016. Harrison facebook and survey monkey and research. https://www.deakin. edu.au/_data/assets_/pdf_file/0008/709892/ Harrison-Facebook-and-Surv ey-Monkey-andresearch.pdf. [14th July 2019]

Jolanda H. 2008. International entrepreneurship: An introduction. Framework and Research Agenda 2(34).

Kamaruddin H, Othman N, Hassan R, W Zaki WMD, Md Sum S. 2017. The Government's Role in the Importance of Entrepreneurship Education Amongst University Students in Malaysia, Leadership, Innovation and Entrepreneurship as Driving Forces of the Global Economy 2016. In ICLIE Springer Proceeding in Business and Economics. hlm 579-587. https://doi. org/10.1007/978-3-319-43434-6_49

Lisa M. 2008. The SAGE Encyclopedia of Qualitative Research Methods. Los Angeles: Sage Publication.
Ministry of Higher Education. 2019. http://mohe.gov.my/en/search ?search word=2016-2020\&searchphrase=all. [10th May 2020].

Nagalakshmi R, Treved M. 2015. Utilization of online survey tools for academic research: a practical approach to survey monkey. The International Journal Research Publication 4(3):21-28.

Omoruyi EMM, Olamide KS, Gomolemo G, Donath OA. 2017. Entrepreneurship and economic growth: Does entrepreneurship bolster economic expansion in Africa?. Journal of Socialomics 6(4):1-11. https://doi.org/10.4172/21670358.1000219

Paolucci E, Sansone G, Fiore E. 2019. Entrepreneurship education in a multidisciplinary environment: Evidence from an entrepreneurship programme held in Turin. Administrative Sciences 9(1):2840. https://doi.org/10.3390/admsci9010028

Rahim HL, Abdul Kadir MAB, Zainal Abidin Z, Junid J, Kamaruddin L, Mohd Lajin F, Buyong SZ, Ahmad Bakri A. 2015. Entrepreneurship education in Malaysia: A critical review. Journal of Technology Management and Business 2(2):1-11.

Sani R. 2018. Entrepreneurial ecosystems at the university. http://mohe.gov. $\mathrm{my} / \mathrm{e} \mathrm{n} / \mathrm{s}$ e a r ch? s e a r c h w ord $=2016$ 2020\&searchphrase $=$ allfor Business. [10th August 2019].

Schumpeter JA. 1934. The Theory of Economic Development. New York: Oxford University Press.

Sekaran U, Bougie R. 2016. Research Methods: A Skill Building Approach. Ed. ke-7. New Jersey: Wiley.

Shane S, Locke EA, Collins CJ. 2003. Entrepreneurial motivation. Human Resource Management Review 13(2):257-279. https://doi.org/10.1016/ S1053-4822(03)00017-2

SME Corp Malayia. 2019. SME Annual Report 2017/18 - A Connected World: Digitalising SMEs. http://www.smecorp.gov.my/index. php/en/?option=com_content\&view= article\&layout $=$ edit\&id=3342. [11th August 2019].

Stevenson HH, Jarillo JC. 1990. A paradigm of entrepreneurship: Entrepreneurial management. Strategic Management Journal 11:17-27. 
Syed SA, Mohd Jani MF, Omar NA. 2011. An empirical study of success factors of women entrepreneurs in southern region in Malaysia. International Journal of Economics and Finance 3(2):166175. https://doi.org/10.5539/ijef.v3n2p166
Wei X, Liu X, Sha J. 2019. How does entrepreneurship education influence the students' innovation? Testing on the multiple mediation model. Front. Psychol 10(1557). https://doi.org/10.3389/ fpsyg.2019.01557 